\title{
HLA-DRB1 Gene
}

National Cancer Institute

\section{Source}

National Cancer Institute. HLA-DRB1 Gene. NCI Thesaurus. Code C19409.

This gene is involved in immunoregulation and antigen presentation. The gene has

several hundred alleles and polymorphism typing is routinely performed for bone marrow and kidney transplantation. 